\title{
Effect of bauxite addition on densification and mullitization behaviour of West Bengal clay
}

\author{
N S RAUT, P BISWAS, T K BHATTACHARYA and K DAS* \\ Government College of Engineering and Ceramic Technology, 73 A.C. Banerjee Lane, Kolkata 700 010, India
}

MS received 12 May 2008; revised 13 June 2008

\begin{abstract}
The effect of bauxite addition on the densification and mullitization of reaction sintered bauxiteclay mixture had been studied in the temperature range $1400-1500^{\circ} \mathrm{C}$. The maximum bulk density $(2 \cdot 89 \mathrm{~g} / \mathrm{cc})$ and minimum apparent porosity $(0.58 \%)$ was achieved by addition of $50 \mathrm{wt} \%$ bauxite. The impurities present in bauxite and clay formed liquid phase which helped in particle diffusion to aid densification. The X-ray diffraction of sample fired at $1500^{\circ} \mathrm{C}$ showed cristoballite phase gradually disappearing and at the same time mullite and $\alpha-\mathrm{Al}_{2} \mathrm{O}_{3}$ phase appearing at a higher level of bauxite addition. The in situ nascent alumina formed was reactive that facilitated the formation of secondary mullite by solution precipitation mechanism. The presence of bauxite also changed the morphology of the mullite particles. Two types of mullite were distinctly observed in the SEM photographs: elongated primary mullite and equiaxed secondary mullite.
\end{abstract}

Keywords. Bauxite; kaolinite; reaction sintering; primary mullite; secondary mullite; cristoballite.

\section{Introduction}

The phases in the system, $\mathrm{Al}_{2} \mathrm{O}_{3}-\mathrm{SiO}_{2}$, are constituents of many ceramic products. This system is important not in the conventional ceramic products but it is of interest in the advanced ceramic products. Mullite occurs very rarely in nature. Mullite is the only stable phase in the binary system, $\mathrm{Al}_{2} \mathrm{O}_{3}-\mathrm{SiO}_{2}$ (Klug et al 1990; Pask 1990). Mullite is becoming increasingly important in electronic, optical and high temperature applications (Pask et al 1991). Low density $(\rho=3.17 \mathrm{~g} / \mathrm{cc})$, low thermal conductivity $\left(\mathrm{K}=2 \mathrm{Wm}^{-1}\right.$ $\left.\mathrm{K}^{-1}\right)$, low thermal expansion coefficient $\left(\alpha_{20 / 200^{\circ} \mathrm{C}}=4 \times\right.$ $\left.10^{-6} /{ }^{\circ} \mathrm{K}\right)$, low dielectric constant $(\mathrm{K}=6.5$ at $1 \mathrm{MHz})$ and excellent mechanical properties at high temperature (strength in excess of $400 \mathrm{MPa}$ at $1200^{\circ} \mathrm{C}$ ) and low creep rate make mullite ceramic a promising candidate for advanced electrical and structural applications (Schneider and Eberhard 1990; Boch and Chartier 1991). Extensive efforts have been made to synthesize mullite powders (Nurishi and Pask 1982; Okada et al 1991; Rezaie et al 1997; Amutharani et al 1999) and to prepare dense sintered bodies, these methods involve very high cost starting materials and powder processing and are not cost effective for large scale production. The use of kaolinitic clay, kaolinitic clay and alumina or sillimanite as starting materials are cheaper alternatives. The kaolinite $\left(\mathrm{Al}_{2} \mathrm{O}_{3} \cdot 2 \mathrm{SiO}_{2} \cdot 2 \mathrm{H}_{2} \mathrm{O}\right)$ is one of the most used starting materials for aluminosilicate based ceramics due to its common occurrence and good availability. The mullite is formed at elevated tem-

\footnotetext{
*Author for correspondence (kabdkd@yahoo.co.in)
}

perature from kaolinitic clay. But the amount of silica in the clay is much higher than that of stoichiometric mullite $\left(3 \mathrm{Al}_{2} \mathrm{O}_{3} \cdot 2 \mathrm{SiO}_{2}\right)$. This silica combined with the impurities present in the natural clay, forms a glassy phase and cristoballite in addition to the formation of mullite at a temperature higher than $1000^{\circ} \mathrm{C}$. The cristoballite may also transform to a glassy phase with other impurities when kaolinite is fired above $1500^{\circ} \mathrm{C}$. The presence of large amount of glassy phase has a detrimental effect on the mechanical properties of mullite prepared from kaolinite.

The amount of the excess silica in the kaolinite can be utilized by the addition of alumina to produce mullite. The addition of alumina can, therefore, enhance the mullite phase eliminating the glassy phase to improve the mechanical properties. During kaolinite firing, cristoballite was formed from amorphous silica exsoluted during the primary mullite formation (Liu et al 1991).

The presence of sufficient alumina began to react with silica-rich liquid favouring the formation of mullite and therefore, retarding or inhibiting the cristoballite formation, depending on the extensiveness of the aluminaliquid reaction (Liu and Thomas 1994). Regarding the role of alumina in the formation of mullite, it was suggested (Chen et al 2000) that alumina is inert to the formation of primary mullite up to $<1300^{\circ} \mathrm{C}$. In the temperature range $1300-1500^{\circ} \mathrm{C}$, the amount of mullite increases rapidly and the amount of alumina decreases rapidly instead. The increase in mullite amount in this temperature range is contributed by the formation of secondary mullite by dissolution of alumina to silica-rich glass and precipitation of secondary mullite. 
Most of the above works on the reaction sintering between alumina and kaolinitic clays were dealt by the synthetic, pure variety aluminas. But in the present work, natural Indian bauxite was used as the source of alumina. Here an attempt has been made to study the effect of bauxite addition on the densification, mullitization and microstructural development.

\section{Experimental}

The clay (Birbhum District of West Bengal), as one of the principal raw materials, was crushed and beneficiated as per standard method of removal of any adhering impurities (Grimshaw 1971). The other important raw material was bauxite (Saurashtra District of Gujarat), crushed, demagnetized and ground. The physical and chemical characteristics of the raw materials are described in table 1. The amount of bauxite was varied from $10-70 \mathrm{wt} \%$. The batch composition along with sample code followed in this study is given in table 2 . The requisite amounts of clay and bauxite were mixed and ground thoroughly in wet condition for $2 \mathrm{~h}$. The slurry was dried at $110^{\circ} \mathrm{C}$. The dried powder was granulated after mixing with water and sieving through BS 30 mesh. The granules were uniaxially pressed at $600 \mathrm{~kg} / \mathrm{cm}^{2}$ into $25 \mathrm{~mm}$ diameter discs. The pressed samples after drying at $110^{\circ} \mathrm{C}$ for overnight were sintered at $1400^{\circ}, 1450^{\circ}$ and $1500^{\circ} \mathrm{C}$ for $2 \mathrm{~h}$ soaking at the sintering temperature.

Table 1. Chemical and physical properties of the principal raw materials.

\begin{tabular}{lcc}
\hline Constituent oxides & Clay & Bauxite \\
\hline $\mathrm{SiO}_{2}(\%)$ & $45 \cdot 52$ & $2 \cdot 81$ \\
$\mathrm{Al}_{2} \mathrm{O}_{3}(\%)$ & $36 \cdot 10$ & $60 \cdot 00$ \\
$\mathrm{TiO}_{2}(\%)$ & $1 \cdot 56$ & $1 \cdot 70$ \\
$\mathrm{Fe}_{2} \mathrm{O}_{3}(\%)$ & $1 \cdot 72$ & $1 \cdot 85$ \\
$\mathrm{MgO}(\%)$ & $\mathrm{Trace}$ & trace \\
$\mathrm{CaO}(\%)$ & $0 \cdot 53$ & trace \\
$\mathrm{Na} 2 \mathrm{O}(\%)$ & $0 \cdot 67$ & trace \\
$\mathrm{K} 2 \mathrm{O}(\%)$ & $0 \cdot 75$ & trace \\
$\mathrm{LOI}(\%)$ & $13 \cdot 25$ & $32 \cdot 17$ \\
$\mathrm{Crystalline} \mathrm{phases} \mathrm{present:}$ & & \\
$\quad \mathrm{Major}$ & $\mathrm{Kaolinite}$ & Gibbsite \\
$\quad$ Minor & - & Anatase \\
DTA peaks & & \\
Endothermic $\left({ }^{\circ} \mathrm{C}\right)$ & $530^{\circ}$ & $360^{\circ}$ \\
Exothermic $\left({ }^{\circ} \mathrm{C}\right)$ & $973^{\circ}$ & - \\
Mean particle size $(\mu \mathrm{m})$ & 3 & - \\
\hline
\end{tabular}

Table 2. Batch composition and the sample code used in the study.

\begin{tabular}{lrcccc}
\hline Sample code & B0 & B10 & B30 & B50 & B70 \\
\hline Clay (wt\%) & 100 & 90 & 70 & 50 & 30 \\
Bauxite (wt\%) & 0 & 10 & 30 & 50 & 70 \\
\hline
\end{tabular}

The bulk density and apparent porosity were measured by water displacement method using Archimedes' principle. The phase analyses of the raw materials and sintered samples were done by X-ray powder diffraction using $\mathrm{Ni}$ filtered $\operatorname{CuK} \alpha$ radiation. Microstructural analyses by scanning electron microscope was performed on fractured surface after chemical etching with $40 \%$ HF for $30 \mathrm{~s}$ followed by thoroughly washing with alcohol and water mixture. The SEM analysis was also done on the mirror polished surface after thermochemical etching.

\section{Results and discussion}

The chemical and physical analyses of the raw materials are described in table 1. The chemical analyses of the

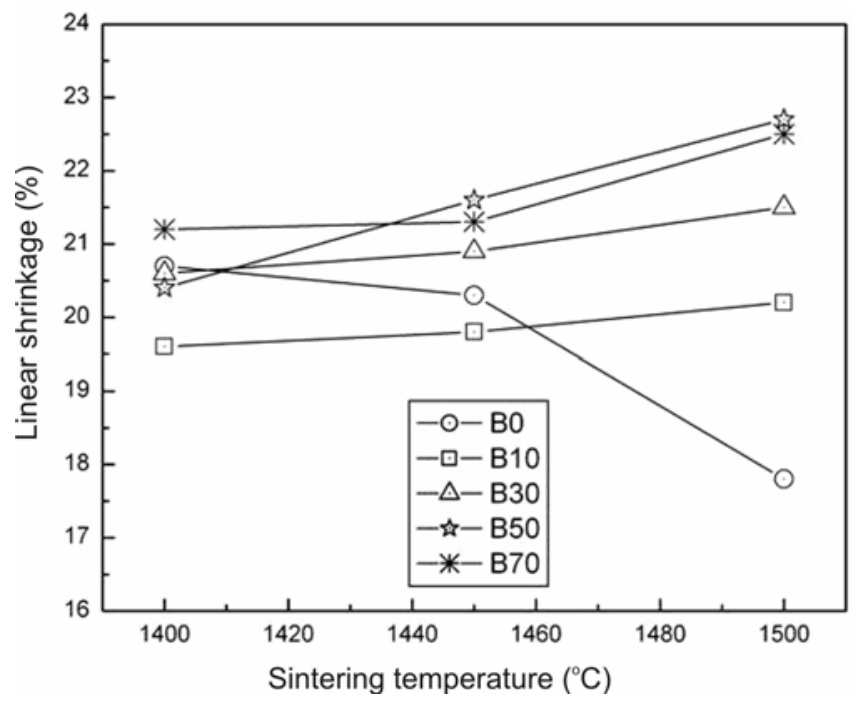

Figure 1. Linear shrinkage as a function of sintering temperature.

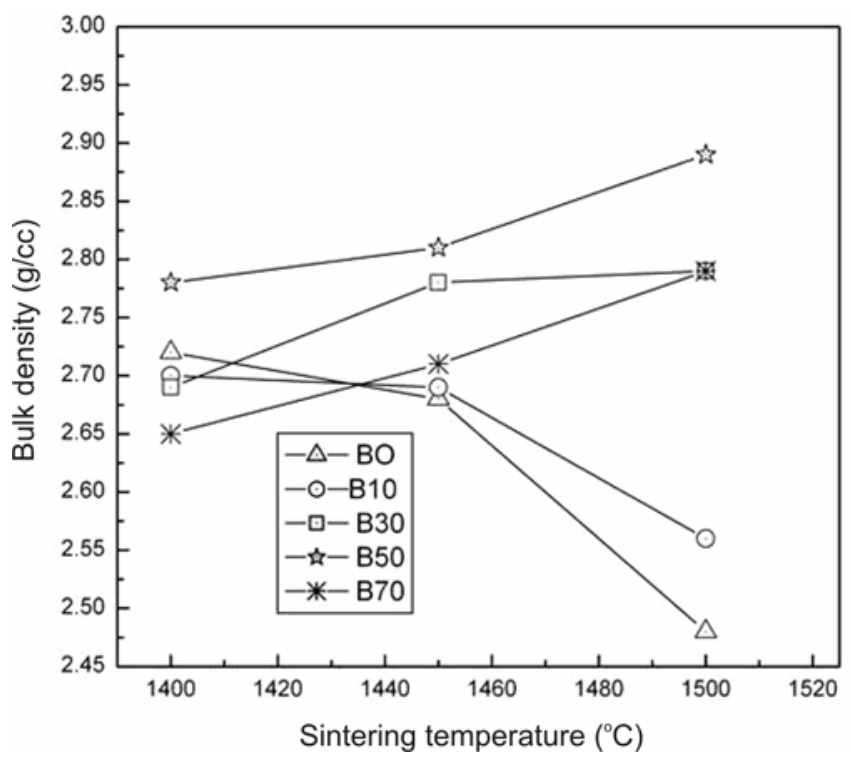

Figure 2. Effect of firing temperature on bulk density of reaction sintered mullite samples. 
clay shows that the silica to alumina ratio is 1.26 close to that of pure kaolinite $(1 \cdot 18)$. The bauxite contains silica, titania and iron oxide as important impurities. The X-ray diffraction pattern of both raw materials corroborates the results of the chemical analysis. The main phases present in the clay and bauxite are kaolinite and gibbsite, respectively. Anatase is the minor impurity phase present in bauxite. The differential thermal analysis showed that the clay had characteristic endothermic peaks at $530^{\circ} \mathrm{C}$ due to the dehydroxylation of kaolinite leading to the formation of metakaolin (Rezaie et al 1997; Viswabhaskaran et al 2003). The exothermic peak at $973^{\circ} \mathrm{C}$ is due to the formation of $2: 1$ mullite and spinel from metakaolin (Johnson

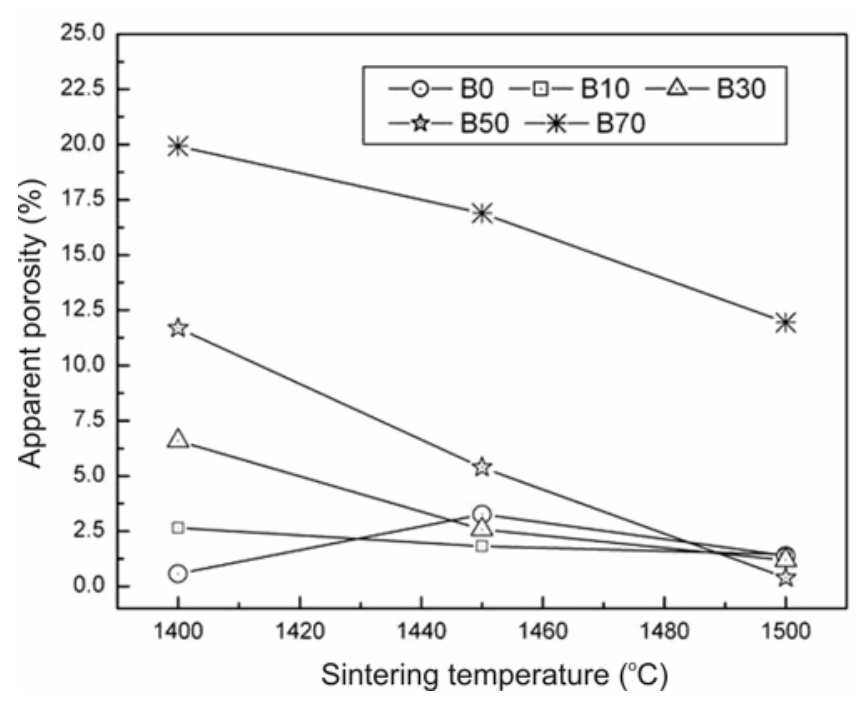

Figure 3. Apparent porosity as a function of sintering temperature.

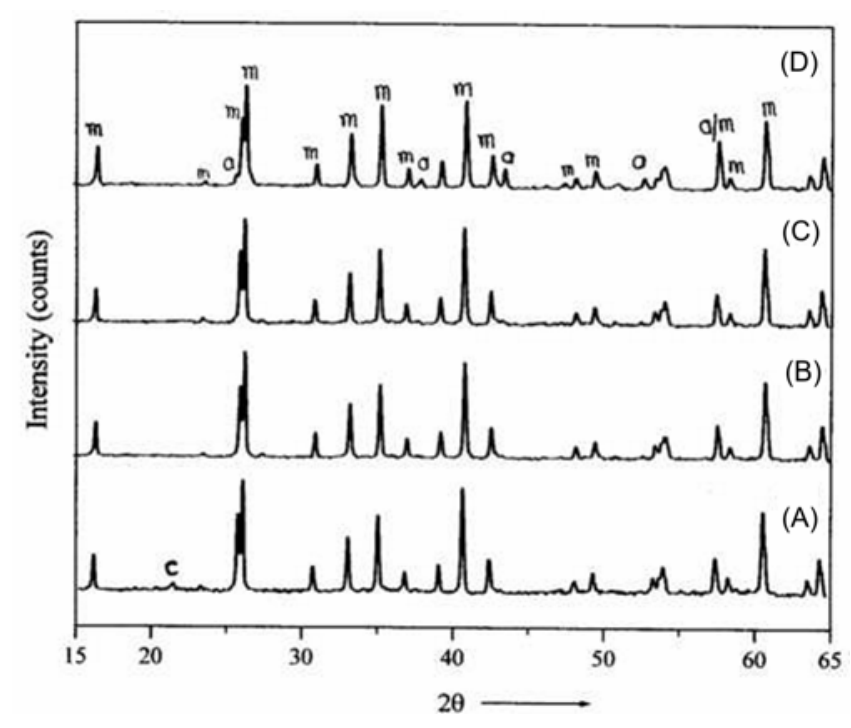

Figure 4. XRD patterns of reaction sintered mullite fired at $1500^{\circ} \mathrm{C}$ : (A) B10, (B) B30, (C) B50 and (D) B70 (m, mullite; c, cristoballite and a, $\alpha$-alumina). et al 1982; Rezaie et al 1997; Viswabhaskaran et al 2003). The bauxite also showed an endothermic peak at $360^{\circ} \mathrm{C}$ due to the dehydroxylation of gibbsite (Kloprogge et al 2002).

The pressed samples were fired at $1400^{\circ}, 1450^{\circ}$ and $1500^{\circ} \mathrm{C}$ for $2 \mathrm{~h}$. The percent linear shrinkage as a function of sintering temperature is shown in figure 1. The linear shrinkage of the bauxite containing samples increases with firing temperature indicating the presence of bauxite helped to densify the samples at high temperature. The maximum shrinkage was observed with the B50 samples at $1500^{\circ} \mathrm{C}$ for $2 \mathrm{~h}$.

The bulk density (BD) and apparent porosity (AP) as a function of firing temperature is plotted in figures 2 and 3 . The samples without bauxite (BO) had maximum BD $(2.72 \mathrm{~g} / \mathrm{cc})$ at $1400^{\circ} \mathrm{C}$ with minimum apparent porosity $(0.58 \%)$. Its value decreased with increasing sintering temperature. The same was observed with $10 \%$ bauxite samples. This decrease in bulk density may be due to the dissociation of $\mathrm{Fe}_{2} \mathrm{O}_{3}$ present in the clay into $\mathrm{FeO}$ and oxygen which is considered to be responsible for bloating in whiteware body at high temperature (Chen et al 2000). The opposite trend was observed in the high bauxite containing samples. With increasing temperature the BD was also increased. The maximum BD with minimum AP was achieved in $50 \%$ bauxite containing samples. The presence of alumina in the bauxite containing samples dilutes the effect of ferric oxide as it can dissolve into mullite at high temperature (Brownel 1958; Johnson and Pask 1982). It was found that the solid solution limit of $\mathrm{Fe}_{2} \mathrm{O}_{3}$ in a synthetic mullite was $7.7 \mathrm{wt} \%$ at $1300^{\circ} \mathrm{C}$. $\mathrm{Fe}^{3+}$ ions can substitute for $\mathrm{Al}^{+3}$ ions due to the similarity in ion size and charge. The impurities present in the bauxite and clay formed higher amount of the glassy phase which facilitated particle diffusion (Bakr and Naga 2002). The in situ nascent alumina formation from bauxite was more reactive to be dissolved in glassy phase along with cristoballite to form secondary mullite by solution precipitation technique (Liu et al 1991). The amount of glassy phase was decreased as the secondary mullite consumed the silica from the glassy phase (Chen et al 2000).

The X-ray diffraction pattern of the powdered samples fired at $1500^{\circ} \mathrm{C}$ are shown in figure 4 . The cristoballite phase is observed with $10 \%$ bauxite samples but no cristoballite peaks were observed with other bauxite containing samples. This observation confirmed that the nascent alumina derived from bauxite in $30 \mathrm{wt} \%$ and higher samples was more reactive and sufficient to dissolve in glassy phase along with cristoballite to form secondary mullite by solution precipitation technique with enhancing densification (Liu et al 1991). The reduction of glassy phase in the bauxite containing samples, the absence of cristoballite and the increase in secondary mullite were responsible for the high BD with high bauxite batches at high temperature. The amount of in situ alumina (10 wt \% batch) was insufficient to form secondary mullite after dissolu- 
tion of cristoballite due to which few cristoballite phases were identified in the XRD. The mullite phase was also observed in all the cases and the mullite peak intensity gradually increased. At $70 \%$ bauxite in addition to mullite phase, $\alpha-\mathrm{Al}_{2} \mathrm{O}_{3}$ phase also appeared. The $50 \%$ bauxite was near the stoichiometric mullite composition and beyond this the excess alumina was crystallized as corundum $\left(\alpha-\mathrm{Al}_{2} \mathrm{O}_{3}\right)$ phase.

The SEM microstructure of $\mathrm{B} 0$ sample fired at $1500^{\circ} \mathrm{C}$ is shown in figure 5 . Considerable growth of mullite crystals are observed. The grains have rounded edges with distinct needle shape. The fully-grown crystals of high aspect ratio are identified. The microstructure is very similar to that obtained by Gnanam et al with South Indian clay (Viswabaskaram et al 2003).

Figure 6 is the SEM of bauxite containing samples fired at $1500^{\circ} \mathrm{C}$ for $2 \mathrm{~h}$. The microstructure shows mullite grain morphology appearing to be a bimodal structure of larger elongated primary mullite crystals with high aspect ratio and smaller, more equiaxed secondary mullite (Liu et al 1991; Sainz et al 2000). The larger mullite crystals with higher aspect ratio corresponded to the primary mullite nucleated in kaolinite and grown in firing. The smaller mullite crystals are secondary mullite nucleated from the transitory liquid phase formed by the dissolution of in situ alumina from bauxite (Chen et al 2000). Figure $6 \mathrm{a}$ is the fired sample of B10 batch showing the higher amount of primary mullite and lower amount of secondary mullite grown from the alumina-rich glassy phase. Formation of mullite from the glassy phase can be noticed. Figure $6 \mathrm{~b}$ is the microstructure of the sintered sample of B30 batch revealing the increasing amount of equiaxed secondary mullite formed from alumina-rich glassy phase. The elongated grains are primary mullite.

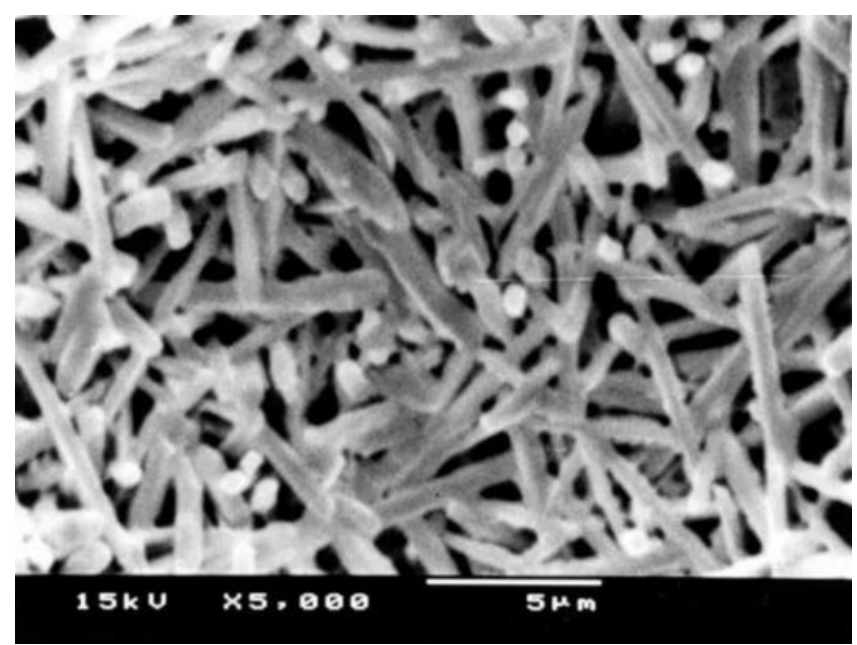

Figure 5. Secondary electron image of mullite without bauxite (B0) sintered at $1500^{\circ} \mathrm{C}$ after chemical etching of fractured surface.
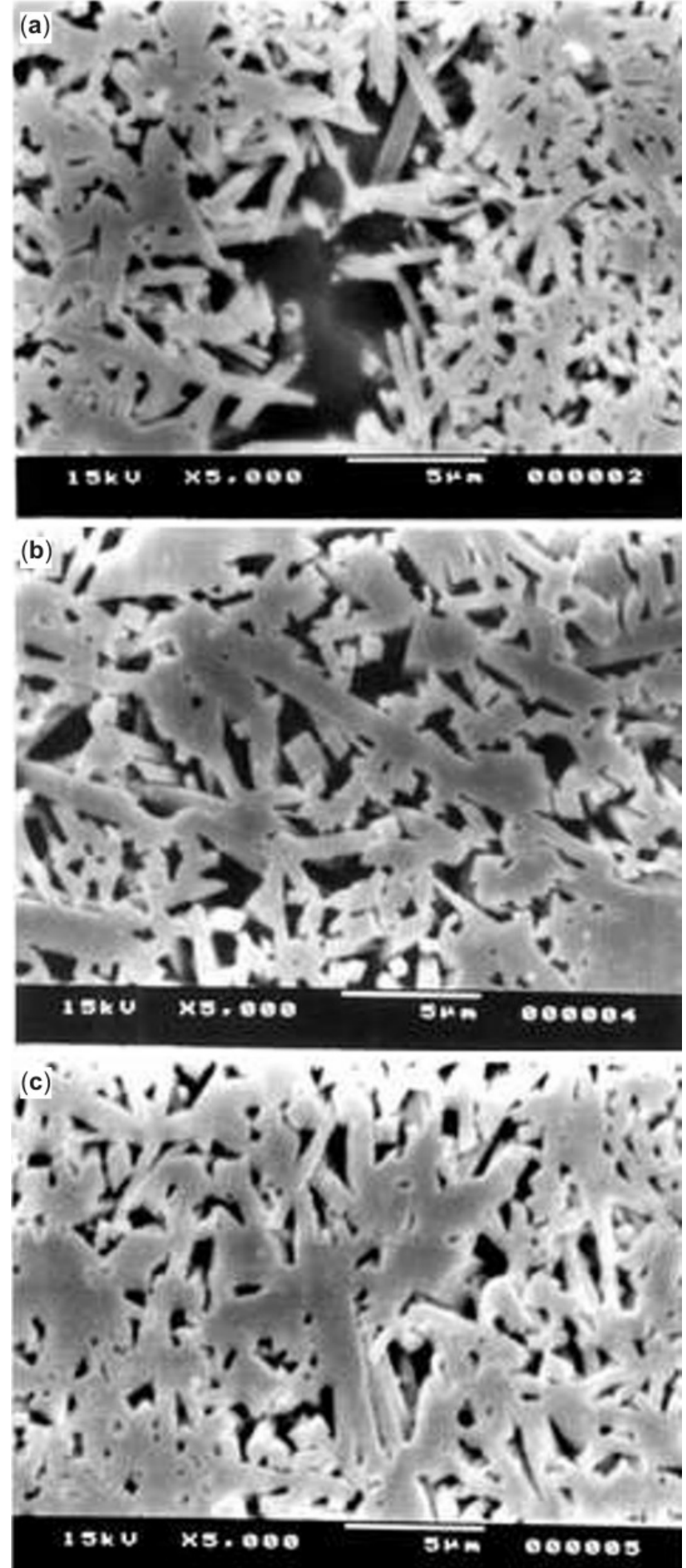

Figure 6. Scanning electron microstructure of mullite with different bauxite contents sintered at $1500^{\circ} \mathrm{C}$ after thermochemical etching of polished surface: (a) B10 showing the presence of primary mullite and formation of secondary mullite from glassy phase (black area), (b) B30 showing the presence of primary and secondary mullite with uniform distribution of glassy phase (black area) and (c) B50 shows the compact microstructure consisting of primary and secondary mullite with minimum glassy phase. For sample codes, see table 2. 
The glassy phase is uniformly distributed. In figure $6 \mathrm{c}$ the bauxite containing sample (B50) sintered at $1500^{\circ} \mathrm{C}$ for $2 \mathrm{~h}$ is shown. The amount of secondary mullite is much higher than the previous two microstructures. The glassy phase is small and the microstructure is compact which corroborates with the $\mathrm{BD}$ value. With increasing bauxite content the amount of glassy phase decreased with increase in the secondary mullite content in place of primary one. The nascent alumina (from bauxite) can act as the nuclei for the formation of secondary mullite grains. The increase of bauxite increases the amount of nuclei and decreases the amount of glass, the size and aspect ratio of mullite grains are thus reduced (Chen et al 2000).

\section{Conclusions}

The present study demonstrated that mullite can be prepared by reaction sintering of kaolinitic clay and bauxite. The presence of bauxite helped to densify the material at low temperature. The impurities present in the bauxite and clay formed glassy phase that facilitated the material diffusion to favour the densification. On the other hand, the in situ alumina formation from natural bauxite was reactive enough to form secondary mullite by solution precipitation technique.

With increase in bauxite content the amount of secondary mullite increased in lieu of glassy phase and cristoballite which ultimately enhanced the bulk density and optimized the BD at $50 \mathrm{wt} \%$ bauxite. Two types of mullite were distinctly observed in the microstructure: larger, elongated primary mullite from kaolinite and smaller, equiaxed secondary mullite by solution precipitation technique from alumina and silica rich glassy phase. The increase in the alumina content increased the amount of mullite nuclei and decreased the amount of glass, the size and aspect ratio of mullite were thus reduced (secondary mullite).

\section{Acknowledgement}

The authors would like to express their gratitude to Prof. P G Pal, Head, Department of Ceramic Technology, Kolkata, for his discussion and support during the work.

\section{References}

Amutharani D and Gnanam F D 1999 Mater. Sci. Engg. A264 254 Bakr M and Naga S M 2002 Br. Ceram. Trans. 101133

Boch P and Chartier T 1991 J. Am. Ceram. Soc. 742448

Brownel W E 1958 J. Am. Ceram. Soc. 41220

Chen C Y, Lan G S and Tuan W H 2000 J. Euro. Ceram. Soc. 202519

Grimshaw R W 1971 The chemistry and physics of clay and allied materials (London, Ernest Benn Ltd.) 4th ed. p. 329

Johnson S M, Pask J A and Moya J S 1982 J. Am. Ceram. Soc. 6531

Johnson S M and Pask J A 1982 Am. Ceram. Soc. Bull. 61838

Klug F J, Prochazka S and Doremur R H 1990 Mullite and mullite matrix composites (ed.) S Somiya et al (Westerville: Am. Ceram. Soc.) pp. 15-43

Kloprogge J T, Ruan H D and Frost R L 2002 J. Mater. Sci. 37 1121

Liu K C and Thomas G 1994 J. Am. Ceram. Soc. 771545

Liu K C, Thomas G, Caballero A, Moya J S and De Aza S 1991 Ceramics Today-Tomorrow's Ceramics, Material Sci. Monographs A66 177

Nurishi Y and Pask J A 1982 Ceram. Int. 857

Okada K, Otsuka N and Somiya S 1991 Am. Ceram. Soc. Bull. 701633

Pask J A 1990 Mullite and mullite matrix composites (ed.) S Somiya et al (Westerville: Am. Ceram. Soc.) pp. 1-13

Pask J A, Dabbs D M and Sarikaya M 1991 J. Am. Ceram. Soc. 742343

Rezaie H R, Rainforth W M and Lee W E 1997 Br. Ceram. Trans. 96181

Schneider H and Eberhard E 1990 J. Am. Ceram. Soc. 732073

Sainz M A, Serrano F J, Amigo J M, Bastida J and Caballero A 2000 J. Euro. Ceram. Soc. 20403

Viswabaskaran V, Gnanam F D and Balasubramanian M 2003 Ceram. Int. 29561 